\title{
BIOREMEDIATION OF A SPENT METALWORKING FLUID WITH AUTO- AND ALLOCHTHONOUS BACTERIAL CONSORTIA
}

\author{
BIOREMEDIACJA ZUŻYTEGO PŁYNU OBRÓBKOWEGO METALI \\ Z WYKORZYSTANIEM KONSORCJÓW BAKTERII \\ AUTO- I ALOCHTONICZNYCH
}

\begin{abstract}
Spent mineral oil-based metalworking fluids are waste products of the machining processes and contribute substantially to the global industrial pollution with petroleum oil products. Wastewaters containing oily emulsions are ecologically hazardous and thus a variety of methods have been implemented to prevent these effluents from affecting the natural environment. Most of these methods rely upon physical-chemical treatment and phase separation; however, none of them proved to be effective enough to meet tightening environmental regulations. Therefore, novel technologies need to be elaborated and there is growing interest in implementing biological treatment methods based on microbial bioremediation. In this study an oil/water emulsion obtained from a waste stream of the metal-processing industry was tested for biodegradability of its organic constituents. This liquid waste was found non-toxic to bacterial consortia and was colonized with indigenous microorganisms (approx. $10^{7} \mathrm{cfu} \cdot \mathrm{cm}^{-3}$ ). The total load of organic content was determined as a chemical oxygen demand (COD) value of $48200 \mathrm{mg} \mathrm{O} \mathrm{O}_{2} \cdot \mathrm{dm}^{-3}$. Emulsion treatment was carried out using a threefold wastewater dilution and employing two variants of biostimulated aerobic bacterial communities: (1) uninoculated emulsion, where bioremediation was carried out by the autochthonous bacteria alone, and (2) wastewater samples inoculated with a ZB-01 microbial consortium which served as a source of specialized bacteria for process bioaugmentation. Biodegradation efficiency achieved in a 14-day test was monitored by measuring both the COD parameter and the concentration of high-boiling organic compounds. Both approaches yielded satisfactory results showing significant reduction of the emulsion organic fraction; however, the resultant decrease of wastewater load tended to be more efficient for the case where the process was bioaugmented with the inoculated consortium. Gas chromatography analyses coupled with mass spectrometric detection (GC-MS) confirmed high degradation yields obtained for both cases studied (58 and 71\%, respectively) in a 28-day test. It is concluded that oil-based metalworking emulsions can undergo efficient biological treatment under conditions enabling aerobic bacterial proliferation and that xenobiotic biodegradation kinetics can be accelerated by bioaugmenting the process with allochthonous microbial consortia.
\end{abstract}

Keywords: metalworking fluids, oily emulsions, biostimulation, bioaugmentation, biodegradation, microbial consortia, autochthonous microflora, allochthonous microorganisms

\footnotetext{
${ }^{1}$ Department of Biochemistry, Institute of Plant Biology and Biotechnology, University of Agriculture in Krakow, al. 29 Listopada 54, 31-425 Kraków, Poland, phone +48 12622 5193, email: p.petryszak@ogr.ur.krakow.pl, p.supel@ogr.ur.krakow.pl

*Corresponding author: p.kaszycki@ogr.ur.krakow.pl
} 


\section{Introduction}

Oily wastewaters are regarded as main industrial pollutants of soil and aquatic environments. They can occur as free-floating oil, unstable or stable oil-in-water $(\mathrm{O} / \mathrm{W})$ emulsions, and in the case of extreme organic load, as water-in-oil (W/O) emulsions. Technological streams of oil-containing wastewaters are discharged by several dominant industrial branches such as crude oil refining, edible oil and meat processing in food industry as well as in metallurgy. The necessity for treatment of these wastewaters has focused much attention because of high environmental risk caused by contamination with oily substances.

Spent $\mathrm{O} / \mathrm{W}$ emulsions contribute profoundly to the total oily wastewater volume discharged by the industry $[1,2]$. The main sources of the $\mathrm{O} / \mathrm{W}$ emulsion waste are the so-called cutting or metalworking fluids (MWFs) [3]. MWFs are industrial fluids used in metal grinding and cutting where they act as lubricants, cooling factors and rust controlling agents in machining processes [1,3,4]. Nowadays, technological practice is dominated by the use of mineral oil- based MWFs, occurring especially in the emulsified $(\mathrm{O} / \mathrm{W})$ form [1, 4], besides the efforts to introduce biologically-based MWFs and synthetic fluids [4-8]. The annual use of the MWFs exceeds 2 million $\mathrm{m}^{3}$ worldwide [9, 10]; however, the final volume of wastewater discharge may be even 10 times higher since technological processes require MWF dilution. MWFs are usually very chemically complex. Apart from oil-derived xenobiotics they contain a number of additives including biocides, heavy metals, surfactants and many other agents [3, 11]. In addition, cutting fluids are often contaminated by various bacterial (both gram-negative and gram-positive) and fungal strains (for detailed information see the review articles [12-16]). Such indigenous microbial strains may be beneficial for their tolerance towards toxic chemical constituents; however, they are often pathogenic and can cause adverse effects on human health, especially on the respiratory system and skin [3, 17-21]. High contaminant load as well as the chemical and microbiological complexity make the spent MWFs also very hazardous to the environment $[2,9,22,23]$.

The above risks have forced the worldwide environmental authorities to tighten regulations regarding the MWF use, treatment and disposal [9, 10, 23-25]. In addition, water-miscible MWF emulsions can hamper conventional wastewater treatment processes. Therefore the disposal of such waste streams directly to sewage systems is strictly forbidden and manufacturing companies are urged to treat their waste on-site [2, 10]. The reuse of spent MWFs is not practically possible due to their chemical ageing and microbiological deterioration $[1,4,26]$. For the reasons described above there is a strong need to elaborate economically-efficient and technologically reasonable methods to treat the MWFs streams. Most of the efforts taken to date have relied upon physical and chemical treatment or mechanical attempts towards oil phase separation [1, 10]. Among the elaborated techniques are: chemical or electrochemical pretreatment (flocculation, coagulation, destabilization, electrochemical splitting), gravity or membrane separation as well as thermal emulsion breaking, vacuum evaporation and finally, incineration [1, 2, 9, 10, 27-32].

All the listed methods are insufficient, however, in terms of the current strict ecological legislation requirements. For that reason microbiological remediation has been proposed as an advantageous and high-yield method, which may serve as a cost-competitive, low energy demanding and environment-friendly alternative [10, 11, 32-37]. The applicability of 
biological methods is particularly high for the treatment of water-miscible emulsions. In such a case the organic phase becomes available to microorganisms while the costs of waste management with conventional methods increase profoundly due to difficulties in separation of the dispersed phase [1].

However, to optimize final effects of MWF bioremediation, several problems must be considered prior to launching any bioprocess. Since microbiological techniques are based on the microbial enzymatic activities the toxicity of contaminants has to be tested, first. Then, it should be verified whether the wastewater environment enables microflora to grow and metabolize hydrocarbon xenobiotics [9]. Such preliminary evaluation is necessary for each particular MWF waste effluent because different technological processes generate spent emulsions varying in their chemical content and contaminant load, which in turn may affect biodegradability [9, 32]. In addition to the above, enough care must be taken to ensure proper stability maintenance of the developed microbial population as pointed out by some authors $[1,9,38]$.

Microbiological treatment of the MWF emulsions may be performed employing both the autochthonous bacteria that colonize particular wastewater and the specialized allochthonous strains which are cultivated under controlled laboratory conditions and then become inoculated for process bioaugmentation. The first strategy involves either biostimulation of the indigenous microflora within the treated MWF [9, 39] or selection of the most active strains from various MWF samples, then cultivation and inoculation to a new wastewater to be treated [9, 30, 34, 35, 40-42]. The use of indigenous microorganisms is of a special interest since their resistance to a complex chemical content of MWFs might result in elevated xenobiotic biodegradation activity [13, 14, 40, 43].

The second strategy requires introduction of bacterial isolates obtained from different niches and revealing unique biochemical activities. This approach should be explored more thoroughly since it has focused only limited attention to date [42]. We believe that the application of allochthonous bacteria may enrich the working biocenosis with rare biochemical activities enabling biodegradation of particularly recalcitrant xenobiotics. Such a synergy effect could be crucial in terms of the final treatment result.

In this study, a microbiological method is proposed for the treatment of a heavily-loaded wastewater, that is a water-miscible, oil-based, spent metalworking fluid. A combined bioprocess is suggested which employs the autochthonous microflora occurring within the emulsion together with the exogenously applied bacterial consortium consisting of specialized microorganisms capable of biodegrading recalcitrant petroleum oil-derived xenobiotics.

\section{Materials and methods}

\section{The metalworking fluid (MWF)}

A spent MWF tested in this study was an effluent discharged by the local metal processing plant where it had been used for metal grinding, cutting and forming. The sample was an inhomogeneous oil-in-water $(\mathrm{O} / \mathrm{W})$ emulsion characterized by a chemical oxygen demand (COD) value of $48200 \mathrm{mg} \mathrm{O} \mathrm{O}_{2} \cdot \mathrm{dm}^{-3}$. It was earlier found to be colonized with indigenous bacterial microflora at a density of $1.36 \cdot 10^{6} \mathrm{cfu} \cdot \mathrm{cm}^{-3}$ (cfu - colony-forming units). The detailed characteristics of the effluent are provided elsewhere [44]. 


\section{Biodegradation tests}

Biodegradation observations lasted typically for 14 or 28 days and were carried out at conditions earlier determined [44] as the most favorable ones for microbial communities, ie fully aerobic growth (vigorous shaking on thermostated laboratory shakers allowing free oxygen penetration) at $25^{\circ} \mathrm{C}$. The samples were typically incubated in $300 \mathrm{~cm}^{3}$ flasks, each containing $50 \mathrm{~cm}^{3}$ of a tested fluid. No additional supplementation with any trophic substances was necessary to sustain growth and reach maximum biomass. Due to the relatively high organic contaminant load, the original MWF suspension was diluted threefold with the sterile water prior to experiments. Two bioremediation variants were tested: (i) the uninoculated emulsion where only the autochthonous bacteria were stimulated to proliferate (depicted as "autochthons" in Figure legends) and (ii) the emulsion inoculated with a specialized microbial consortium ZB-01 (see below) for process bioaugmentation (depicted as "auto- + allochthons").

\section{Bacterial consortium used for bioaugmentation}

A microbial ZB-01 consortium was used to bioaugment bioremediation of xenobiotics in the tested MWF. Typically, the oily emulsion was inoculated with ZB-01 (initial cell density of approx. $5 \cdot 10^{8} \mathrm{cfu} \cdot \mathrm{cm}^{-3}$ ) at a 334-fold dilution (by adding $3 \mathrm{~cm}^{3}$ of ZB-01 to a $1 \mathrm{dm}^{3}$ of the sample). ZB-01 is a biodiverse biocenosis earlier constructed at Biochemistry Department, University of Agriculture in Krakow, and grown under selective conditions to form a stable, biologically balanced microbial community consisting of a number of bacterial strains, capable of biodegrading environmentally recalcitrant organic xenobiotics. All the constituent microorganisms are naturally occurring environmental isolates collected at ground-water sites long-term polluted with petroleum-derived hydrocarbons. More details on the consortium development, cultivation and applications are given elsewhere [45-47].

\section{Microbiological monitoring}

Bacterial cell population density was monitored as earlier described [44, 47] with a Koch surface-plating method. Briefly, $25 \mathrm{~mm}^{3}$ volumes of sample serial dilutions were spread onto agar-solidified optimal media (2.5\% enriched agar, Biomed, Poland). Prior to dilutions, in order to obtain homogeneous cell suspensions, each MWF specimen $\left(1 \mathrm{~cm}^{3}\right)$ was sonicated under mild conditions for $10 \mathrm{~min}$ with a laboratory ultrasound washer (UN-2 Unitra/Unima, Poland). Colony forming units were counted after $3 \mathrm{~d}$ incubation at $37^{\circ} \mathrm{C}$ and the resultant cell frequencies were expressed as $\mathrm{cfu}$ per $\mathrm{cm}^{3}$ of original samples.

\section{Analytical procedures}

Chemical oxygen demand (COD) was determined with a dichromate procedure according to the protocols of the standardized Hach-Lange DR5000 (Germany) automated ampoule-based analytical system, in accordance with the Hach-Lange LCK 914 COD Test manufacturer's manual.

The organic content of the MWF samples was extracted with petroleum ether (fractions $40-60^{\circ} \mathrm{C}$, POCh, Poland) using a modified standardized protocol published previously [46]. Briefly, a $10 \mathrm{~cm}^{3}$ sample was weighed, thoroughly mixed (laboratory vortex shaker), acidified with $1 \mathrm{~cm}^{3}$ of $18 \% \mathrm{HCl}$ and dried with approx. $30 \mathrm{~g}$ of anhydrous $\mathrm{MgSO}_{4}$. The sample was then placed in a nitrocellulose extraction thimble (Sigma-Aldrich) 
and extracted in a $65 \mathrm{~cm}^{3}$ Soxhlet apparatus at 40-60 extraction runs (approximately $6 \mathrm{~h}$ ). The extractions were carried out at least in duplicates. After evaporating the excess solvent at $85^{\circ} \mathrm{C}$, the flasks containing extracted material were dried at $105^{\circ} \mathrm{C}$ for $1.5 \mathrm{~h}$, then cooled in a vacuum desiccator and finally, high-boiling $\left(>105^{\circ} \mathrm{C}\right)$ residual material was weighed.

Gas chromatography analyses with a mass spectrometric detection (GC-MS) were done on a Shimadzu GC-17A ver.3 gas chromatograph coupled with a QP-5000 mass spectrometer equipped with an auto-sampler Shimadzu AOC-20i. A capillary $60 \mathrm{~m}$ column SLB-5ms (Supelco, USA) was filled with a non-polar bed (5\% phenyl, 95\% methyl residues, $\Phi=0.25 \mathrm{~mm}$, film thickness: $0.25 \mu \mathrm{m})$. Helium 5.0 was used as a carrier gas. The analyte sample volume was $1 \mu \mathrm{l}$; temperature program: initial temp. $50^{\circ} \mathrm{C}, 5 \mathrm{~min}$, then increase by $5^{\circ} \mathrm{C} \cdot \mathrm{min}^{-1}$ till $310^{\circ} \mathrm{C}$, maintained for $20 \mathrm{~min}$. Temperature of the injection chamber and the linker: $330^{\circ} \mathrm{C}$; mode of action: ,solvent cut off time”, 9 min; method for data detection: total ion current (TIC) within the mass ion range of 35 to $500 \mathrm{~m} / \mathrm{z}$ (time range: 10 to $78 \mathrm{~min}$ ). Chromatographic data were collected using the Shimadzu GCMS Solution ver 1.1 Software. Xenobiotic contents were calculated as areas under the respective chromatographic profiles and expressed as the \% value of the initial amount (ie untreated MWF).

\section{Statistical data and error analysis}

COD values and the content of organic substances were averaged based on two independent analyses. Microbiological frequency was determined upon three repetitions. The mean experimental error, represented by the respective error bars in Figures, was calculated on the basis of multiple repetitive analyses of each of the above parameters and was assumed as 10, 15 and 12\%, respectively. The GCMS chromatographic analyses were always made in duplicates. The error bars in GCMS results represent standard deviations calculated for each individual sample.

All the chemicals were of analytical grade. Whenever required, sterile conditions were applied.

\section{Results}

Based on a set of microbiological tests published earlier [44] the studied MWF emulsion proved non-toxic to allochthonous bacterial communities and revealed the presence of indigenous microflora population of the order of $10^{6} \mathrm{cfu} \cdot \mathrm{cm}^{-3}$. These characteristics suggested that the fluid might be susceptible to biological treatment.

\section{Cell population dynamics in the MWF upon biostimulation and bioaugmentation}

When the ZB-01 consortium (initial bacterial biomass density of $5 \cdot 10^{8} \mathrm{cfu} \cdot \mathrm{cm}^{-3}$ ) was inoculated (at 334-fold dilution, that is 3:1000, $v / v$ ) to the tested MWF emulsion (diluted threefold), bacteria kept their survivability rate and revealed the ability to further proliferate. Xenobiotics were seemingly non-toxic and served as an efficient carbon source for microbial growth (Fig. 1, dark gray-bars). Similar result was observed for the uninoculated sample (Fig. 1, light bars), where only autochthonous bacteria were monitored.

Figure 1 also shows ( $c f$. time 0 and 1 day of incubation) that right after the start of the experiment for both cases studied there was observed a dramatic increase (close to two orders of magnitude) in bacterial population. The reason for this rapid initial biomass 
increase was apparently a biostimulation effect caused by efficient aeration and active agitation on rotary shakers, which favored aerobic growth and caused better availability of the organic fraction of the emulsion. The xenobiotic content must have served as a carbon source since no supplementation with any other trophic agents was provided. Biostimulation was thus considered as the first key condition triggering bioremediation. The second important factor was the presence of allochthonous bacteria introduced to bioaugment the process. The inoculation enabled the developing mixed biocenosis to grow more dynamically and to exceed the indigenous microorganism frequency ( $c f$. the respective dark-gray and light-gray bars of Figure 1). The difference in microbial population became significant at day $7\left(2.0 \cdot 10^{9} \mathrm{cfu} \cdot \mathrm{cm}^{-3}\right.$ and $6.8 \cdot 10^{8} \mathrm{cfu} \cdot \mathrm{cm}^{-3}$, respectively), and then tended to grow to reach a 25 -fold higher biomass at the end of the test (day 28 , $4.0 \cdot 10^{7} \mathrm{cfu} \cdot \mathrm{cm}^{-3}$ and $1.6 \cdot 10^{6} \mathrm{cfu} \cdot \mathrm{cm}^{-3}$, respectively). The favorable effect of introducing specialized bacteria on the bioremediation yield is confirmed by the appropriate biodegradation tests presented below.

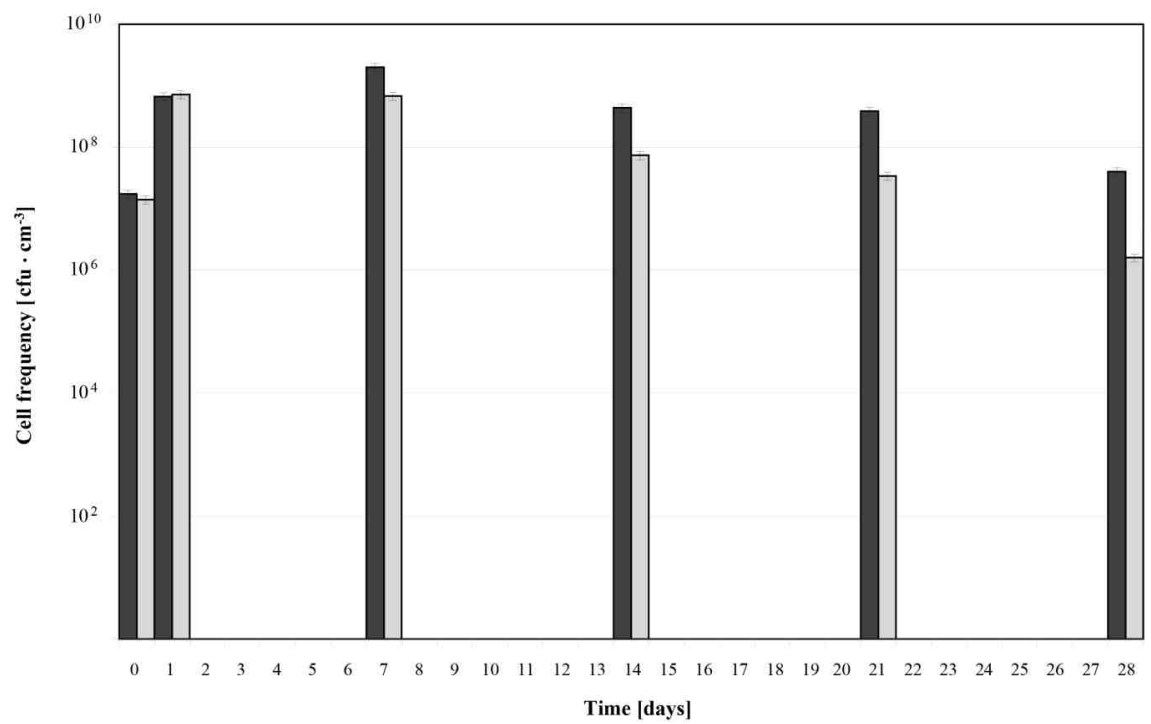

Fig. 1. Microorganism population dynamics throughout the MWF bioremediation test. Explanations: dark-gray bars - sample inoculated with the ZB-01 consortium (3:1000, v/v) prior to the experiment (day 0); light bars - uninoculated sample (autochthons only)

\section{Biodegradation of the petroleum ether-extractable organic fraction}

The fraction of high-boiling $\left(T_{b}>105^{\circ} \mathrm{C}\right)$ organic compounds in the treated emulsion samples, as determined with petroleum-ether extraction method, was degraded significantly only in experimental variant involving indigenous microflora bioaugmentation with a ZB-01 consortium. A 14 -day test resulted in a $24.8 \%$ biodegradation yield. The organic fraction content in the studied samples is presented in Figure 2. 


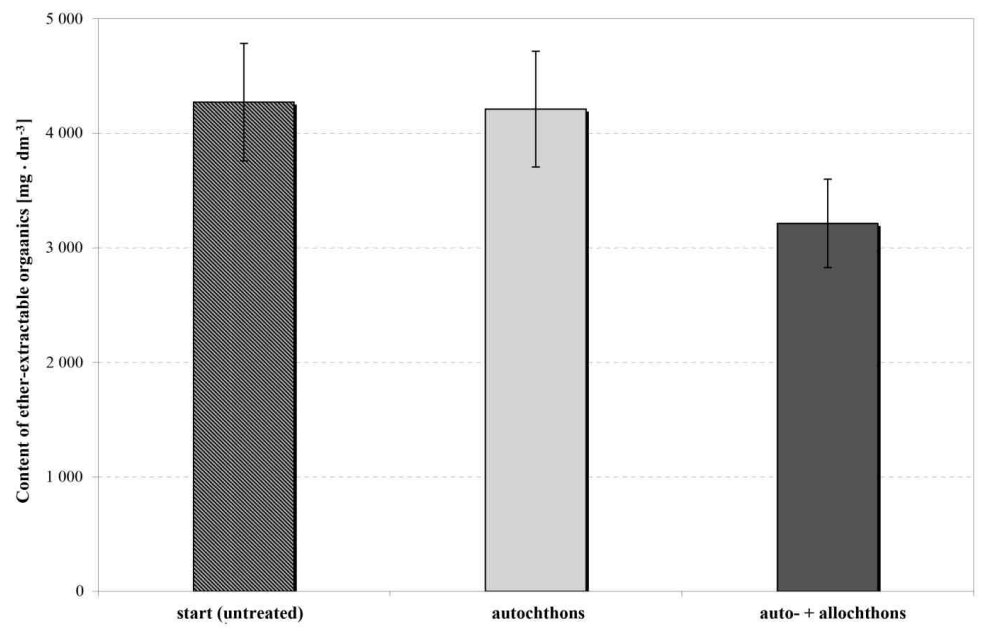

Fig. 2. Content of high-boiling organic compounds in the MWF as observed upon 14-d bioremediation test. Explanations: bars (from left to right) represent the starting level, values obtained upon treatment with biostimulated autochthons, and obtained upon process bioaugmentation with allochthonous bacteria (ZB-01 consortium); other conditions were as described above

\section{COD (chemical oxygen demand) observations}

The COD parameter determinations were carried out to reveal changes of the total organic pollutant load of the waste fluid during treatment. The results are presented in Figure 3 and they correspond to the ones presented above.

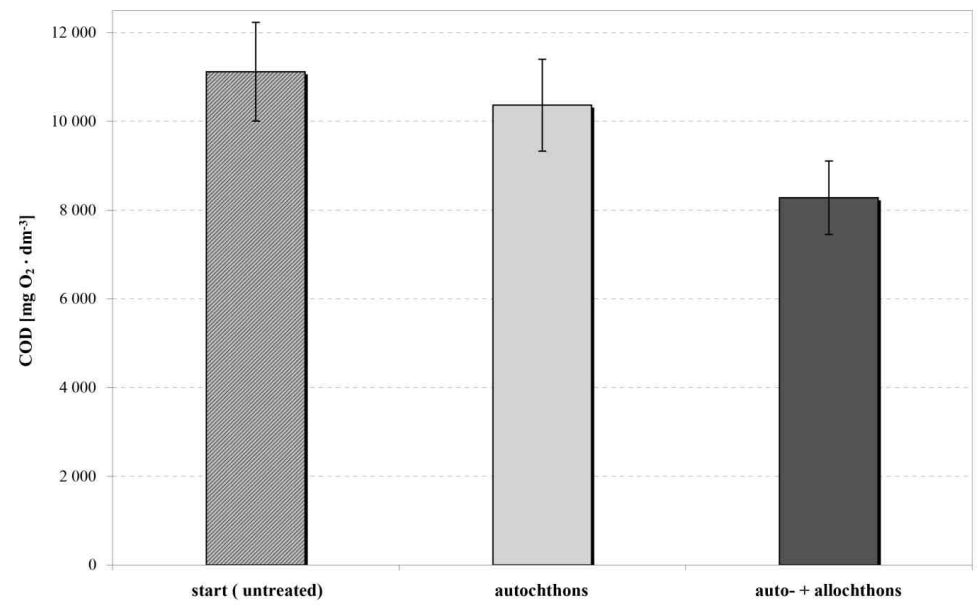

Fig. 3. Changes of a COD parameter as observed in the MWF upon 14-d bioremediation. Explanations: see Figure 2 
In the 14-d biodegradation process the only case of significant COD decrease was observed for the inoculated sample, and the final yield was calculated as $25.6 \%$. The slight $7 \%$ decrease of the COD value determined for the non-bioaugmented sample might represent some activity of the indigenous bacteria, although it has to be noted that this result remains within the experimental error.
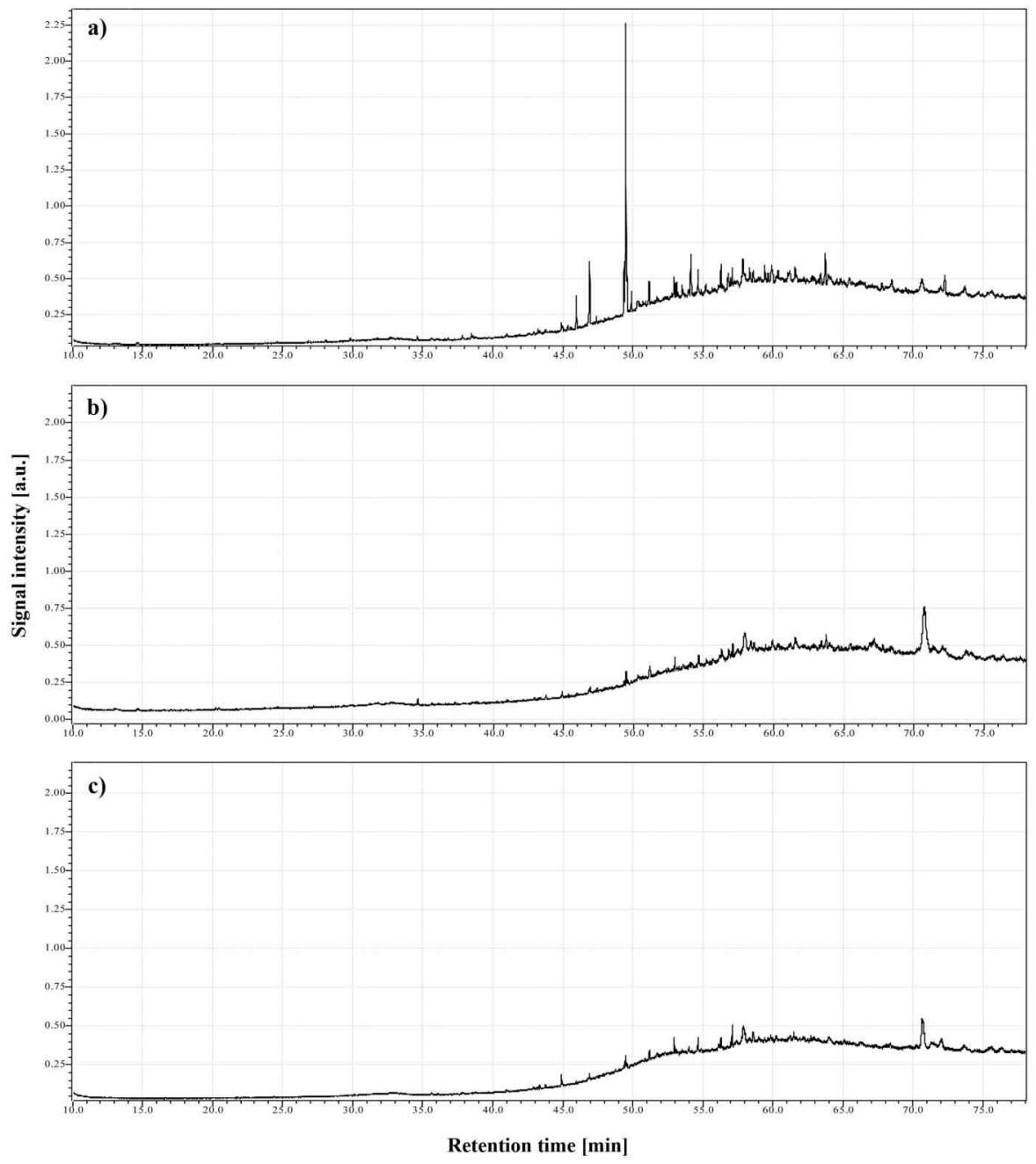

Fig. 4. Chromatographic GC-MS profiles obtained after 28-d biodegradation of the MWF (threefold dilution) carried out with: b) biostimulated autochthons alone; c) autochthons together with the allochthons inoculated as a ZB-01 consortium $(3: 1000$, v/v); a) untreated sample (a control profile) 


\section{GC-MS analyses}

Gas-chromatography analysis of the organic fractions extracted from the emulsion fluid was carried out after completing the bioremediation test (28 days of treatment). For both samples studied (uninoculated as well as inoculated MWF), a high-yield biodegradation of the GC-detectable analytes was shown. Detailed GC-MS chromatographic profiles are presented in Figure 4 a, b and c, for the raw (untreated) emulsion, for the MWF treated with autochthonous microorganisms, and for the MWF enriched with a ZB-01 consortium, respectively.

The chromatogram shown (Fig. 4a) reveals the presence of over 100 distinct peaks. Upon the emulsion treatment the number of detectable analytes tended to decrease. Taking into consideration the 26 dominant analytes that contributed to approximately $90 \%$ of the total chromatogam area, the lower number was finally detected for the case of bioaugmented biodegradation than for uninoculated sample (Table 1).

GC-MS analysis of the diversity of dominant xenobiotic fractions upon MWF biotreatment (28 d)

\begin{tabular}{|c|c|}
\hline MWF emulsion sample & No. of analytes detected with GC-MS \\
\hline untreated & 26 \\
\hline $\begin{array}{c}\text { treated with autochthonous microflora } \\
\text { (inoculated with ZB-01) }\end{array}$ & 20 \\
\hline \begin{tabular}{c} 
treated with auto- and allochthonous microflora \\
\hline
\end{tabular} & 15 \\
\hline
\end{tabular}

It should be noted here that a lack of a particular analyte at given retention time may suggest complete biodegradation or, at least, biotransformation into another metabolic intermediate that would appear elsewhere in the profile.

Figure 5 compares the total xenobiotic content in the tested samples.

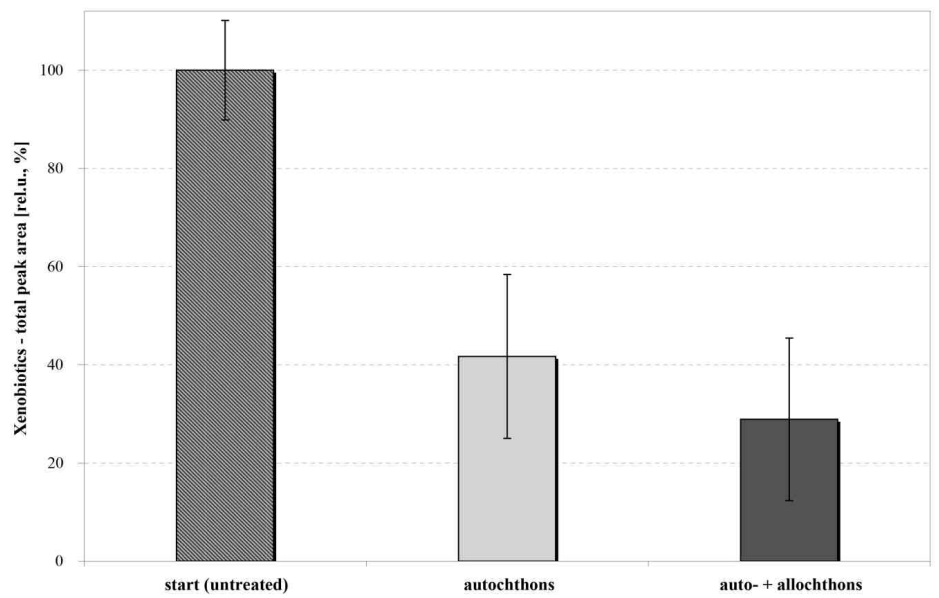

Fig. 5. Biodegradation efficiency (28-d) as monitored with GC-MS. Explanations: bars represent the total amount of xenobiotic compounds as represented by areas under chromatographic profiles obtained for the following samples (from left to right): untreated MWF emulsion, MWF treated with biostimulated autochthonous bacteria, and MWF treated with the mixed auto- and allochthonous biocenosis 
As it can be seen, the resultant value dropped dramatically and was statistically significant. The calculated biodegradation yields exceeded 58 and $71 \%$ for the emulsion treated with the autochthonous and with the mixed (auto- and allochthonous) biocenoses, respectively. These results, again, point to the bioaugmented process as the most efficient one, which is in accordance with the conclusions made earlier upon testing with the other methods (see above). However, due to the high analytical error of the GCMS data the evaluation of the two treatment approaches has no statistical support.

\section{Discussion}

Among recent MWF treatment trends there are processes combining various techniques in order to meet high environmental standards. The sequential approach involves three operational stages: a primary treatment applied to mechanically remove the free-oil phase, secondary step aimed at braking $\mathrm{O} / \mathrm{W}$ emulsions and removal of the dispersed oil, and tertiary treatment based on biological degradation of the remaining emulsified and dissolved oil $[1,10,30]$. The so-called hybrid processes make use of more than one separation techniques that complement one another and they may be supported by biological treatment stage $[1,9]$. Such integrated processes take the advantage of the novel technological as well as biotechnological achievements to reduce total treatment costs, energy consumption, and finally to give the most efficient result $[1,9,10,30,32,34,40,41,43,48]$.

Microbiologically-based treatment processes make use of the activities of activated sludges working in aeration chambers of wastewater treatment plants or of bacterial consortia constructed upon specialized strains [9, 22, 34, 35, 39, 40, 42]. Bioremediation of recalcitrant MWF constituents was shown to be effective either with aerobic or anaerobic methods [9, 14, 39, 49]. However, in general the aerobic process, as compared to the anaerobic one, resulted in better COD removal rates and higher contribution of biodegradation mechanism $[14,50]$. It thus appears that the anaerobic treatment technology requires further optimization actions such as supplementation with complementary physical-chemical processes, addition of co-substrates and/or extensive bioaugmentation $[50,51]$.

In this work a water-miscible, oil based metalworking fluid was subjected to fully aerobic bioremediation without any preliminary treatment. The main aim of the study was to show that the emulsion could be efficiently treated with a microbiological method. One of the most important novelties of the proposed approach was to prove the applicability of allochthonous bacterial consortia used to bioaugment biodegradation reactions within the tested MWF.

Bacteria of the ZB-01 consortium have been selected from various polluted sites containing numerous contaminants of different chemical structure. Thus, it was expected that bioaugmentation with these microorganisms might be crucial for enabling the newly formed microbial community to biodegrade the whole spectrum of xenobiotics present in the metalworking fluid. The observed lack of toxicity for either autochthonous or allochthonous bacteria does not necessarily imply that the biodegradation potential would be high against all the xenobiotics, especially regarding the most resistant fractions such as branched aliphatic hydrocarbons, aromatic and polyaromatic compounds or chemical additives. 
However, although the resultant decrease in MWF organic load could be clearly observed for both tested approaches, the degradation yield proved higher for the bioaugmented process. A straightforward explanation of these phenomena would be that the indigenous biocenosis was capable of utilizing only a part of the organic fraction that was the most metabolically accessible and abundant enough to ensure high bacterial frequency throughout the test. This carbon-source abundance could be expected on the basis of the high organic content of the tested emulsion ( $c f$. the COD value). The application of a ZB-01 inoculum, in turn, apparently enabled the mixed biocenosis to utilize additional recalcitrant compounds thanks to the enrichment with highly specialized strains.

For any cleanup project it is important that all the pollutants are eliminated and the total contamination load is expected to decrease substantially. It should be stressed here that each of the methods employed to monitor bioremediation brings information about the content of different carbon fractions. In this context, the experimental variant employing both, auto- and allochthonous biocenoses gave the most satisfactory results since it was the only one that proved effective by all the analytical techniques used for evaluation (that is the decrease of COD, extractable organic fraction as well as qualitative and quantitative GC-MS measurements).

We note that biodegradation rates obtained for the models tested in this study were calculated upon a limited observation time (14 or 28 days) which implies that the results represent only some stage of the process still being carried out by bacterial biocenoses. This fact should be combined with the high initial value of the organic contaminant load $\left(\mathrm{COD}=11116 \mathrm{mg} \mathrm{O} \mathrm{O}_{2} \cdot \mathrm{dm}^{-3}\right)$. Taking into consideration both of the above conditions the final bioremediation yield should be thus considered good.

At the same time it is difficult to confront our data with the results of other authors. Although these teams dealt with a similar subject their methodologies involved different approaches such as a long-term simulated wastewater flow setup [39], mixed anoxic/aerobic SBR cycles [35], combined two-step anaerobic/aerobic process [39], hybrid physical-biological or chemical-biological treatments $[34,41]$ or high dilution of the MWF wastewater (concentrations below 3\%) [42]. Moreover, it has to be emphasized that different working-fluid sources generate effluents varying dramatically in their chemical content. A single MWF product can consist of even 60 different chemical compounds, and over 300 substances are known to be used during cutting fluids production and application $[1,9,11]$. Therefore, when comparing various MWFs ecotoxicities, contents of organic and inorganic contaminants, and finally biodegradabilities, the specificity of the individual industrial processes must be taken into account.

To show the best MWF treatment results reported to date the work of Kim et al [39] should be mentioned. The authors achieved $88 \%$ process yield (COD decrease from $3300 \mathrm{mg} \mathrm{O}_{2} \cdot \mathrm{dm}^{-3}$ to about $400 \mathrm{mg} \mathrm{O} \cdot \mathrm{dm}^{-3}$ ) in continuous, simulated-flow biodegradation tests conducted either with an aerobic chamber or a two-step anaerobic/aerobic bioreactor. Using a stabilized and enriched microbial consortium, Hilal et al [34] were able to reduce the wastewater load up to $90 \%$ (from $6000-9000 \mathrm{mg} \mathrm{O} \mathrm{O}_{2} \cdot \mathrm{dm}^{-3}$ to $700-2000 \mathrm{mg} \mathrm{O} \mathrm{O}_{2} \cdot \mathrm{dm}^{-3}$ ). Their results were even better (the end value of 800-1200 $\mathrm{mg} \mathrm{O}_{2} \cdot \mathrm{dm}^{-3}$ ) when effluent recirculation was applied. A 30\% COD removal efficiency (from 9980 to $7028 \mathrm{mg} \mathrm{O} \mathrm{O}_{2} \cdot \mathrm{dm}^{-3}$ ) was reported by Connolly et al [41] and $70 \%$ by MacAdam et al [10] (MWF added at relatively low concentrations; COD ranged from 412 to $998 \mathrm{mg} \mathrm{O}_{2} \cdot \mathrm{dm}^{-3}$ ). Moscoso et al [42] in a 2-week biodegradation test employing 
the specialized, MWF-isolated bacterial consortia were able to reduce the total petroleum hydrocarbon (TPH) fraction by $50 \%$. In the same work the authors proved even higher TPH biodegradation yield (up to 70\%) using monocultures of a Pseudomonas stutzeri isolate. It should be noted here that the researchers stated that $3 \%$ of microbial inoculum $(v / v)$ was sufficient to launch dynamic biodegradation of a spent MWF. Our study shows that the ZB-01 biocenosis proved efficient upon significantly lower inoculation (about $0.3 \%, v / v$ ).

The tested microbiological remediation approach applied for the management of the MWF-based emulsion waste can be easily scaled up to the technical level. It is also believed to be economically acceptable especially when contrasted to the other, physical-chemical treatment methods as described in Introduction. In particular, the amount of bacterial inoculum required to launch bioremediation process is relatively low $(3: 1000, v / v$, that is three liters of the pre-grown culture per cubic meter of the MWF) and can be easily obtained [45] provided the specialized microbial consortium is available. The other conditions such as vigorous agitation (paddle or air compressor-based agitation), active aeration system (fine-bubble technique using mini-compressors) and temperature maintenance $\left(25^{\circ} \mathrm{C}\right)$ can be easily implemented and are not expensive [52].

\section{Conclusions}

Water-miscible, spent metalworking fluids can be biologically treated provided they are non-toxic to microorganisms capable of xenobiotics biodegradation. If the MWF emulsions are colonized with autochthonous strains efficient treatment is achievable when the indigenous microflora is properly biostimulated to proliferate and reveal the necessary enzymatic potential. The tested oil/water emulsion generated as a waste stream of the metal processing industry was shown to undergo microbiological treatment upon activities of both autochthonous and allochthonous bacteria. However, the fraction of organic contaminants was reduced significantly better when the bioprocess was augmented with specialized bacteria. For that purpose a pre-grown microbial ZB-01 consortium was used, which consisted of unique strains adapted to the presence of organic pollutants and specialized at metabolizing hydrocarbon compounds. Bioaugmentation not only accelerated the treatment process but also enabled to eliminate a wider set of particular xenobiotics. Microbiological treatment was monitored using various analytical techniques such as gravimetric analyses (Soxhlet extraction of high-boiling organic compounds), chemical oxygen demand (COD) measurements, and gas-chromatography coupled with mass spectrometry (GC-MS). Apparently, inoculation with the consortium led to enrichment of the active biocenosis with bacteria able to biodegrade the most recalcitrant substances.

The study proves that the proposed approach to aerobically treat MWFs with biostimulated indigenous bacteria together with bioaugmented microbial consortia can be regarded as a cheap and efficient method with the potential of application on the industrial scale. We believe that such a simple, single-step microbial bioprocess can be further improved by taking relevant optimization actions in order to accomplish the expected high bioremediation yield. 


\section{Acknowledgements}

The work was financially supported by the grant for scientific research no. 3500, approved by the Polish Ministry of Science and Higher Education and by Mo-BRUK S.A., Niecew 68, Korzenna, Poland.

\section{References}

[1] Coca J, Gutierrez G, Benito JM. Treatment of oily wastewater. In: Coca-Prados J, Gutierrez-Cervello G, editors. Water Purification and Management. NATO Science for Peace and Security Series - C: Environmental Security. Dordrecht: Springer-Verlag; 2011.

[2] Lazarević FB, Krstić IM, Lazić ML, Savić DS, Skala DU, Vejlković VB. Hem Ind. 2013;67(1):59-68. DOI: 10.2298/HEMIND120317055L

[3] Geier J, Lessmann H. Metalworking fluids. In: Frosch PJ, Menne T, Lepoittevin J-P, editors. Contact Dermatitis. 3rd edition. Berlin Heidelberg: Springer; 2006.

[4] da Silva EJ, Bianchi EC, de Aguiar PR. Revista de Ciencia \& Technologia. 2001;8(18):67-77.

[5] Biresaw G. Inform Champaign. 2004;15:148-149.

[6] Shashidhara YM, Jayaram SR. Tribol Int. 2010;43:1073-1081. DOI: 10.1016/j.triboint.2009.12.065

[7] Lawal SA, Choudhury IA, Nukman Y. Int J Mach Tool Manuf. 2012;52:1-12. DOI: 10.1016/j.ijmachtools.2011.09.003.

[8] Wichmann H, Stache H, Schmidt Ch, Winter M, Bock R, Herrmann Ch, et al. J Clean Prod. 2012;43:12-19. DOI: 10.1016/j.jclepro.2012.12.042.

[9] Cheng C, Phipps D, Alkhaddar RM. Water Res. 2005;39:4051-4063. DOI: 10.1016/j.watres.2005.07.012.

[10] MacAdam J, Ozgencil H, Autin O, Pidou M, Temple C, Parsons S, et al. Environ Technol. 2012;33(24):2741-2750. DOI: 10.1080/09593330.2012.678389.

[11] Rabenstein A, Koch T, Remesch M, Brinksmeier E, Kuever J. Int Biodeter Biodegr. 2009;63(8):1023-1029. DOI: 10.1016/j.ibiod.2009.07.005.

[12] Janda K, Przybulewska K. Postępy Mikrobiol. 2004;43(2):167-187.

[13] Bakalova S, Doycheva A, Ivanova I, Groudeva V, Dimkov R. Biotechnol Biotechnol Eq. 2007;21(4):437-441. DOI: 10.1080/15459621003741631.

[14] Thompson IP, van der Gast CJ. The microbiology of metal working fluids. In: Timmis KN, editor. Handbook of Hydrocarbon and Lipid Microbiology. Berlin Heidelberg: Springer-Verlag; 2010.

[15] Saha R, Donofrio RS. Appl Microbiol Biotechnol. 2012;92:1119-1130. DOI: 10.1007/s00253-012-4055-7.

[16] Trafny EA. Int J Occup Med Environ Health. 2013;26(1):4-15. DOI: 10.2478/S13382-013-0075-5.

[17] Mirer FE. Am J Ind Med. 2010;53(8):792-801. DOI: 10.1002/ajim.20853.

[18] Cyprowski M, Piotrowska M, Zakowska Z, Szadkowska-Stańczyk I. Int J Occup Med Environ Health. 2007;20(4):365-371. DOI: 10.2478/v10001-007-0036-y.

[19] Cyprowski M. Bezp pracy. 2012;9:16-19.

[20] Park DU, Jin KW, Koh DH, Kim BK, Kim KS, Park DY. J Occup Health. 2008;50(2):212-220. DOI: 10.1539/joh.07006.

[21] Murat JB, Grenouillet F, Reboux G, Penven E, Batchili A, Dalphin JC, et al. Appl Environ Microbiol. 2012;78(1):34-41. DOI: 10.1128/AEM.06230-11.

[22] Gerulova K, Mihalkova A, Sergovicova M, Guoth A, Nadasska Z. Res Papers Faculty Materials Sci Technol Slovak Univ Technol. 2011;19(31):45-56. DOI: 10.2478/v10186-011-0055-1.

[23] Grijalbo L, Fernandez-Pascual M, Garcia-Seco D, Gutierrez-Manero FJ, Lucas JA. J Hazard Mater. 2013;260:220-230. DOI: 10.1016/j.jhazmat.2013.05.026.

[24] Water Framework Directive 2000. European Parliament (2000/60/EC). http://eur-lex.europa.eu, access: 20 January 2014.

[25] Effluent limitations guidelines and new source performance standards for the metal products and machinery point source category; Final Rule. US Environmental Protection Agency, Federal Register. 2003;68(92).

[26] Theaker D, Thompson I. The industrial consequences of microbial deterioration of metal working fluid. In: Timmis KN, editors. Handbook of Hydrocarbon and Lipid Microbiology. Berlin Heidelberg: Springer-Verlag; 2010.

[27] Hu X, Bekassy-Molnar E, Vatai G, Koris A. Environ Prot Eng. 2005;31(3-4):109-118.

[28] Saifuddin N, Chua KH. Biotechnology. 2006;5(3):308-314. DOI: 10.3923/biotech.2006.308.314. 
[29] Cambiella A, Ortea E, Rios G, Benito JM, Pazos C, Coca J. J Hazard Mater. B. 2006;131:195-199. DOI: 10.1016/j.jhazmat.2005.09.023.

[30] Muszyński A, Załęska-Radziwiłł M, Łebkowska M, Nowak D. Arch Environ Contamn Toxicol. 2007;52(4):483-488.

[31] Gutierrez G, Benito JM, Coca J, Pazos C. Ind Eng Chem Res. 2009;48(4):2100-2106. DOI: 10.1021/ie801054d.

[32] Jagadevan S, Graham NJ, Thompson IP. J Hazard Mater. 2013;244-245:394-402. DOI: 10.1016/j.jhazmat.2012.10.071.

[33] Kim BR, Rai DN, Zemla JF, Lipari F, Harvath PV. Water Res. 1994;28(6):1453-1461. DOI: 10.1016/0043-1354(94)90313-1.

[34] Hilal N, Busca G, Waller MD. J Chem Technol Biotechnol. 2005;80: 641-648. DOI: 10.1002/jctb.1241.

[35] Muszyński A, Łebkowska M. Pol J Environ Stud. 2005;14(1):73-79.

[36] Cheng C, Phipps D, Alkhaddar RM. Water Environ J. 2006;20:227-232. DOI: 10.1111/j.1747-6593.2005.00010.x.

[37] Anderson JE, Lofton TV, Kim BR, Mueller SA. Water Environ Res. 2009;81(4):357-364.

[38] van der Gast CJ, Thompson IP. Biotechnol Bioeng. 2005;89(3):357-366. DOI: 10.1002/bit.20351.

[39] Kim BR, Anderson SG, Zemla JF. Water Environ Res. 1992;64(3);258-262.

[40] van der Gast JC, Whiteley AS, Lilley AK, Knowles CJ, Thompson IP. Environ Microbiol. 2003;5(6):453-461. DOI: 10.1046/j.1462-2920.2003.00428.x.

[41] Connolly HE, van der Gast CJ, Wylie D, Stephenson T, Thompson IP. J Chem Technol Biotechnol. 2006;81:1540-1546.

[42] Moscoso F, Deive FJ, Villar P, Pena R, Herrero L, Longo MA, et al. Chemosphere. 2012;86,420-426. DOI: 10.1016/j.chemosphere.2011.10.012.

[43] Jagadevan S, Jayamurthy M, Dobson P, Thompson IP. Water Res. 2012;46:2395-2404. DOI: 10.1016/j.watres.2012.02.006.

[44] Kaszycki P, Supel P, Petryszak P. J Ecol Eng. 2014;15(3):14-22. DOI: 10.12911/22998993.1109117.

[45] Kaszycki P, Szumilas P, Kołoczek H. Inż Ekol. 2001;4:15-22.

[46] Kaszycki P, Pawlik M, Petryszak P, Kołoczek H. Ecol Chem Eng A. 2010;17(4-5):405-414. http://tchie.uni.opole.pl/ece_a/A_17_4-5/ECE_A_17\%284-5\%29.pdf.

[47] Kaszycki P, Petryszak P, Pawlik M, Kołoczek H. Ecol Chem Eng S. 2011;18(1):83-92.

[48] Jagadevan S, Dobson P, Thompson IP. Biores Technol. 2011;102:8783-8789. DOI: 10.1016/j.biortech.2011.07.031.

[49] Kim BR, Zemla JF, Anderson SG, Stroup DP, Rai DN. Water Environ Res. 1992;64:216-222.

[50] Teli A, Vyrides I, Stuckey DC. J Chem Technol Biotechnol. 2014; DOI: 10.1002/jctb.4339.

[51] Rodriguez-Verde I, Regueiro L, Pena R, Álvarez JA, Lema JM, Carballa M. Biores Technol. 2014;155:281-288. DOI: 10.1016/j.biortech.2013.12.090.

[52] Kaszycki P, Petryszak P, Kołoczek H. Ecol Chem Eng A, 2008;15(11):1257-1271.

\title{
BIOREMEDIACJA ZUŻYTEGO PŁYNU OBRÓBKOWEGO METALI Z WYKORZYSTANIEM KONSORCJÓW BAKTERII AUTO- I ALOCHTONICZNYCH
}

\author{
Zakład Biochemii, Instytut Biologii Roślin i Biotechnologii \\ Uniwersytet Rolniczy im. Hugona Kołłątaja w Krakowie
}

\begin{abstract}
Abstrakt: Zużyte płyny obróbkowe metali, powstałe na bazie oleju mineralnego, są produktami odpadowymi przemysłu maszynowego i znacząco przyczyniają się do globalnego skażenia poprzemysłowego substancjami ropopochodnymi. Ścieki zawierające emulsje olejowe stanowią zagrożenie ekologiczne i z tego powodu podjęto szereg działań mających na celu ograniczenie ich negatywnego oddziaływania na środowisko naturalne. Większość stosowanych metod opiera się na oczyszczaniu i separacji fazowej z wykorzystaniem procesów fizykochemicznych. Żadna z opracowanych technologii nie jest jednak wystarczająco efektywna, aby spełnić coraz ostrzejsze normy środowiskowe. Opracowuje się zatem nowe metody, wśród których rosnące uznanie znajduje oczyszczanie biologiczne, wykorzystujące drobnoustroje zdolne do bioremediacji zanieczyszczeń. W pracy badano możliwości biodegradacji organicznych składników emulsji typu olej/woda, będącej odpadowym płynem obróbkowym przemysłu metalurgicznego. Stwierdzono, że odciek nie był toksyczny wobec konsorcjów
\end{abstract}


bakteryjnych, będąc jednocześnie skolonizowany przez mikroorganizmy autochtoniczne (ok. $10^{7} \mathrm{jtk} \cdot \mathrm{cm}^{-3}$ ). Całkowite obciążenie emulsji związkami organicznymi, wyznaczone jako chemiczne zapotrzebowanie tlenu (ChZT), wynosiło $48200 \mathrm{mg} \mathrm{O} \mathrm{O}_{2} \cdot \mathrm{dm}^{-3}$. Testowano dwa warianty procesowe oczyszczania ścieku trzykrotnie rozcieńczonego $\mathrm{z}$ wykorzystaniem biostymulowanych, aerobowych biocenoz bakteryjnych: (1) emulsja niezaszczepiona, w której bioremediacja prowadzona była wyłącznie przez drobnoustroje autochtoniczne, (2) ściek zaszczepiony konsorcjum mikroorganizmów ZB-01, które stanowiło źródło wyspecjalizowanych bakterii wspomagających bioproces. Wydajność biodegradacji uzyskana w ciągu 14-dniowego testu była mierzona wartością ChZT oraz koncentracją wysokowrzących związków organicznych. Wyniki obu podejść badawczych były zadowalające, a uzyskany spadek zawartości frakcji organicznej znaczący. Jednocześnie stwierdzono większy stopień obniżenia ładunku w ścieku oczyszczanym metodą bioaugmentacji po zaszczepieniu konsorcjum bakteryjnym. Analizy chromatografii gazowej z detekcją spektrometrii mas (GC-MS) potwierdziły wysoką wydajność biodegradacji otrzymaną w ciągu 28 dni dla obu wariantów (odpowiednio 58 i $71 \%$ ). Podsumowując, wykazano, że zaolejone płyny obróbkowe poddają się oczyszczaniu biologicznemu w warunkach pozwalających na proliferację bakterii tlenowych, a kinetyka biodegradacji ksenobiotyków może być przyśpieszana poprzez bioaugmentację procesu konsorcjami drobnoustrojów alochtonicznych.

Słowa kluczowe: płyny obróbkowe metali, emulsje olejowe, biostymulacja, bioaugmentacja, biodegradacja, konsorcja drobnoustrojów, mikroflora autochtoniczna, mikroorganizmy alochtoniczne 